\title{
Intellectual Human Behaviour On Business Environment On 3'c Model
}

\section{DOI:10.36909/jer.ACMM.16325}

\author{
Sathvik $S^{1}$, Atul Kumar Singh ${ }^{2}$,V R Prasath $\operatorname{Kumar}^{3}$, L. Krishnaraj ${ }^{1 *}$ \\ Department of Civil Engineering, Faculty of Engineering and Technology, SRM Institute \\ of Science and Technology, Kattankulathur - 603203, Tamil Nadu, India. \\ *Corresponding Author: Dr L. Krishnaraj, Mail Id-krishnal@srmist.edu.in.
}

\begin{abstract}
The implementation of a building project in any place largely depends on the integration of different stakeholders so that none of them can control or execute the project on their own. Both can be influenced by the practices of project management. There is no universal theoretical basis in the management of this work to define "communication, coordination, and cooperation" (3C). The role of various $3 \mathrm{C}$ concepts is explored in this paper. The business environment and human behaviour are identified as two major parts based on the analysis of selected articles in well-known construction management journals across the various domains. $3 \mathrm{C}$ and its connection to the performance of the construction project. The objective of this article is therefore to explain the definition of $3 \mathrm{C}$ and their relationship between them. The logic of communication and coordination exchange is an important link. As a result, collaboration becomes more difficult and requires more time and effort.
\end{abstract}

Keywords- Communication, Coordination, Cooperation, Human Behaviour. 


\section{INTRODUCTION}

The activities are bifurcated into more detailed levels, the construction industry is fragmented throughout the project life cycle. This situation is considered to be the main reason for low productivity, low efficiency, and low competitiveness. Various interest groups are involved in construction projects. Customers, designers, engineers, contractors, and subcontractors need to work together in the procurement and execution of the project (Xue, X. Li, Q.Shen, \& Y. Wang, 2005). The integration of three key materials, information, and capital flow among relevant personnel is part of construction project management. And competitiveness, forcing builders to establish an effective management system. In the past ten years, there has been a trend of rapid adoption of major initiatives aimed at improving the efficiency of construction projects, so new terminology has been adopted, especially as an operational background, coordination, and collaboration (3C).

The nature of the construction industry is difficult to determine which $3 \mathrm{C}$ method alternatives may be valuable under certain nick or tasks (Fritz, S. Narasimhan, \& H.S Rhee, 1998). The existence of literature gaps, the purpose of this article is to study the existing literature on the $3 \mathrm{C}$ concept. $3 \mathrm{C}$ can be used interchangeably to understand what stakeholders need to do to collaborate effectively.3C is an organized procedure that provides various measures to achieve a common goal and defines the joint efforts of participants in the organization. As the company grows, its $3 \mathrm{C}$ approach is expected to do just that.

However, these methods reduce ambiguity by allowing a short period for accurate feedback and increasing the credibility of the information (Miller \& S. Moser, 2004). 3C can even reduce data processing by sharing relevant information with only relevant stakeholders on time. After all, communication without cooperation is futile, and cooperation without coordination is meaningless. 


\section{RESEARCH METHODOLOGY}

Although "communication, coordination and collaboration" (3C) are common in science and practice, there is no specific definition. $3 \mathrm{C}$ varies between different parts of the literature, depending on the source and subject of the article (Ellingsen \& R. Ostling, 2010). Based on the information available, the emphasis is on extensive information exchange and the integration of long-term activities. In contrast, there has been little ongoing research into the relationship between communication, coordination, and collaboration issues and how they affect project performance individually or collectively shown in Table 1. Dictionary definitions of three terms used in stakeholder construction projects. It can be concluded that there are several definitions suitable for describing 3C conditions. 3' C Model did not describe one term concerning another firmly and correctly. The definition shows $3 \mathrm{C}$ represents the continuous and coordinated collaboration sequence, growth, and growth of relationships initiated by communication. Contact participants is a way to communicate.

Table 1- 3Cs Terms Definition

\begin{tabular}{|c|c|c|}
\hline Dictionary & Webster- Merriam [5] & Cambridge [6] \\
\hline Communication & $\begin{array}{l}\text { "A process through which } \\
\text { information is exchanged } \\
\text { among people through a } \\
\text { common system of signs, } \\
\text { symbols or conduct." }\end{array}$ & $\begin{array}{l}\text { "A two-way process of } \\
\text { mutual understanding, which } \\
\text { involves not just the } \\
\text { exchange but the creation and } \\
\text { sharing of meaning." }\end{array}$ \\
\hline Coordination & $\begin{array}{l}\text { "The functioning of the parts in } \\
\text { harmony with efficient results." }\end{array}$ & $\begin{array}{l}\text { "The act of involving actors } \\
\text { in planning activities } \\
\text { cooperates in an organized } \\
\text { manner." }\end{array}$ \\
\hline Cooperation & $\begin{array}{c}\text { "To work with others or in an } \\
\text { intellectual endeavour in } \\
\text { particular." }\end{array}$ & $\begin{array}{c}\text { "To work with others or in an } \\
\text { intellectual effort in } \\
\text { particular." }\end{array}$ \\
\hline
\end{tabular}


This is an important role in management. As a result, if there is no communication between the organization's hierarchy levels and departments, the organization cannot function. This refers to how participants interact and communicate information (not only "facts", but also politics, opinions, feelings, and thoughts). In most organizations, "misunderstanding" is the most important issue. Most members send messages more effectively than send. Due to its essential coordination and collaboration role, communication characteristics have a significant impact on project efficiency. Communications and response instruments are essential. The information supplied should be as accurate and as straightforward as possible, However, communication is difficult for a variety of reasons. The terminology and process of information exchange vary from organization to organization. Due to misunderstandings or personal differences, we do not want to rely on other organizations. Moreover, there is no consensus on the collection, dissemination of communication information (Fuks, et al., 2008) (Alaloul, M. Liew, \& N. Zawawi, 2016) (Cataldo, P.A. Wagstrom, J.D. herbsleb, \& K.M Carley, 2006).

Coordination is the combination of several components in an organized system to achieve a certain objective. The invisible force that unites all other administrative functions. According to (Mohr, J. Fisher, \& J.R.Nevin, 1996): "Coordination is the act of interdependence between management actions to achieve goals." From an interorganizational point of view, coordination would be explained as an organization with deliberate and organized stakeholder measures to achieve a specific goal. Coordination is usually accomplished through effective communication or information transfer. 


\section{METHODOLOGY}

\section{3'CS MODEL}

This study may be a systematic evaluation of well-known industry journals to trace the $3 \mathrm{C}$ growth of the development industry. A meta-analysis of project management and $3 \mathrm{C}$ cross-border literature in entire disciplines began applied research in this research. Submit literature in construction management articles, in particular in business and human behaviour articles Understanding the rapidly developing environment in this field, the research focuses on articles written in the past ten years.

\section{3'CS FRAMEWORK}

The source of the article is considered the most well-known and most important. Quality sources, and are committed to considering other construction issues. (Lin \& Q. Shen, 2007) for example used keyword research from similar sources to critically discuss the efficiency of value-management research in the building industry. In addition, (Chan, D. Scott, \& E. W. Lam, 2002) identified key design/construction factors and related construction projects. In this study, keywords, titles, and abstracts were searched in articles. Various terms have been used to define $3 \mathrm{C}$, for example. B. "Cooperation, alliances, partnerships, networks, alliances, consortia, teamwork, joint ventures, communities, and coordination".

\section{3'CS STRATEGY}

Therefore, choosing the right keywords for article searches is an important topic and can have a huge impact on your research results. Complete the investigation. First, preliminary tests were performed on all of the upper mentioned conditions. More than 300 projects were received as a result of the results. To improve the efficiency of the review process, we examined the titles and keywords of 300 articles and determined that "communication, coordination, and collaboration" are the most appropriate keywords. 180 
articles are using at least one keyword. Finally, the recovery process of the article is as follows: (1) Use keywords to check the title, keywords, and comments in each article. (2) Evaluate the abstract to determine whether these articles are consistent with the research objectives. (3) After the screening, 34 articles on 3C were used in this research and scanned in detail.

\section{RESULTS AND DISCUSSION}

The volatile business in the construction industry is regarded as extremely competitive, and the complex environment requires construction companies to implement effective management systems (Alaloul, M. S. Liew, \& N. A. B. Zawawi, 2016). 3C is essential to the existence of the organization and increasing the productivity of the construction industry. Cooperation, coordination, and communication with existing organizations are particularly problematic in construction management. You can achieve the comprehensive skills that stakeholders want. The advantage of $3 \mathrm{C}$ 's is that they attract stakeholders, such as increasing opportunities for improvement. This call is based on the fact that $3 \mathrm{C}$ not only shares its efforts but also relies on the knowledge of each participant and can carry out continuous communication. information. Improving the efficiency of organizational processes, as well as the need for more organized resource use, are two issues that must be encouraged. The significance of communication stems from its ability to enable stakeholders to collaborate on common activities or fully achieve common goals.

\section{OVERVIEW OF 3'CS MODEL}

Organizations that only provide communication between stakeholders whose standards are familiar to everyone certainly don't have high-performance projects. There is no correlation between the efforts of stakeholders to coordinate their work. The analysis of the research related to cooperation and coordination shows that most of them individually 
examine the issue of cooperation and coordination. The research team believes the extent to which the association cooperates will impact its components, thus affecting the value of coordination and the other way around (Alaloul, M. S. Liew, \& N. A. W. A. Zawawi, 2016) (Alaloul, M. S. Liew, \& N. A. W. A. Zawawi, 2015). On the other hand, it describes the possibility of related cooperation and associated coordination characteristics, which interactively describe performance instead of independently. Comprehensive and complete complementary cooperation may be also achieved through coordination. Cooperation and coordination influence each other and influence each other on the project. The $3 \mathrm{C}$ connection is shown in Figure $1 \& 2$.

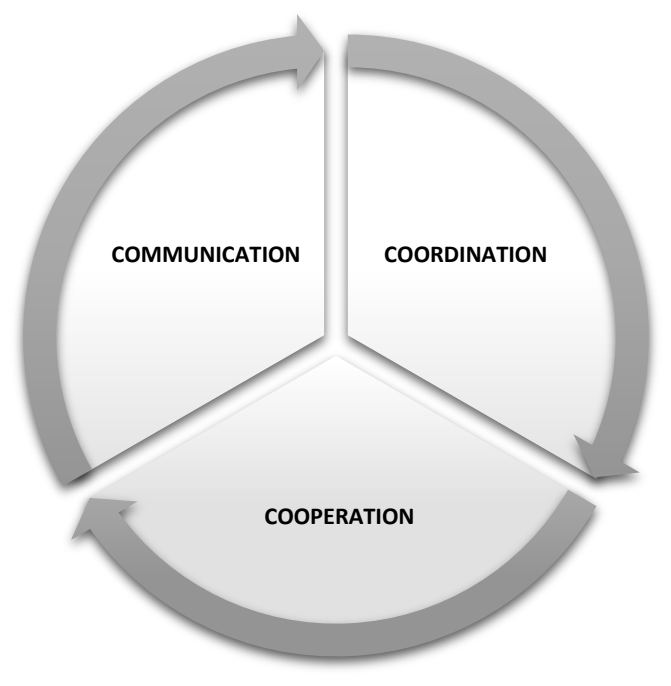

Figure 1- Communication, Coordination and Cooperation triangle relationship

Figure $1 \& 2$ represents the communication requires the commitment of participants to make it coordinated and coordinated to prepare for collaborative tasks. However it is necessary to improve the level of communication to support requirements in cooperation so that $3 \mathrm{C}$ may be interpreted as separately: communication is regarded as a sort of exchange of information depending on the choice of the media, the method of transmission, place, and channel of debate. 


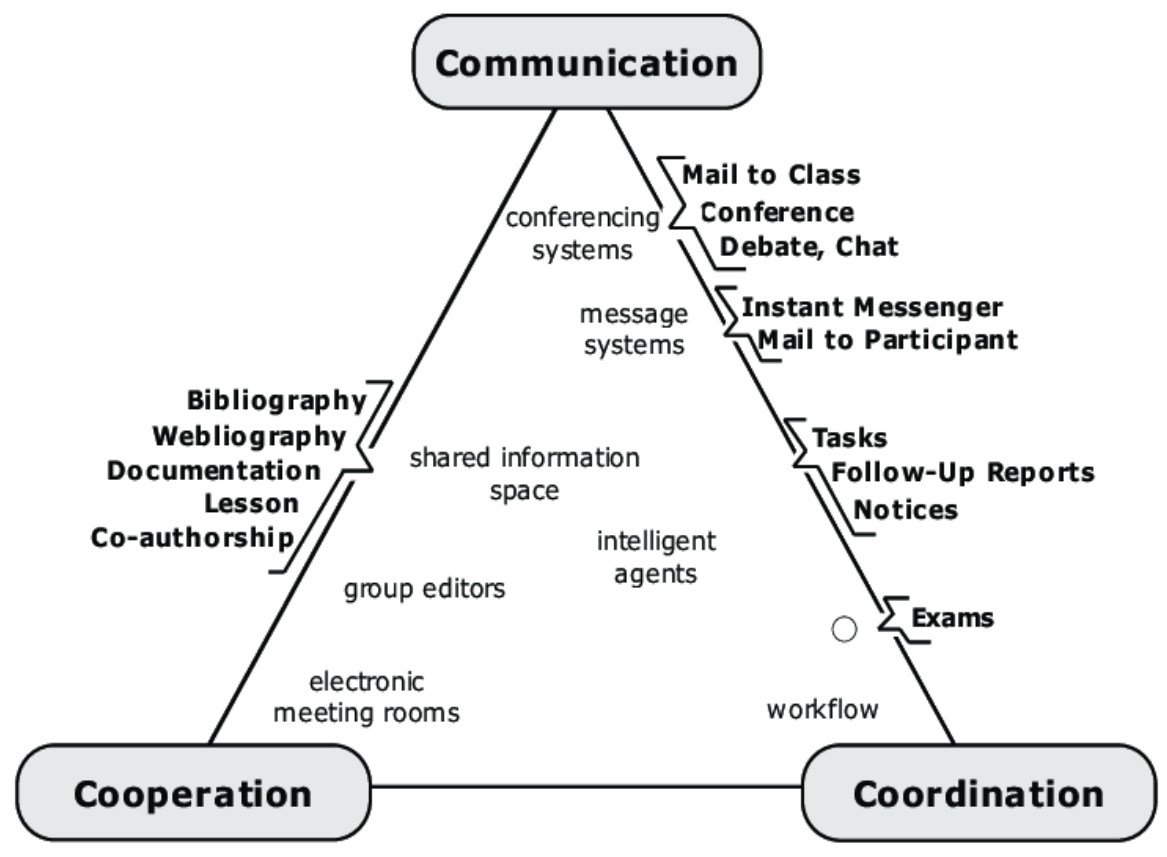

Figure 2- Classification of 3C Model

The coordination of participants, their tasks, and resources is determined by coordination. That's the perception controller. The results shown in Table 2 that can be achieved under joint work are integration and cooperation. This is the workflow or perception of the project life cycle.

Table 2-3C's characteristics comparison

\begin{tabular}{|l|l|l|l|}
\hline \multicolumn{1}{|c|}{ Element } & Commination & Coordination & Cooperation \\
\hline Relationships & $\begin{array}{l}\text { There is no deliberate } \\
\text { organizational mission } \\
\text { and objectives. There } \\
\text { is no time limit for } \\
\text { interaction as needed. }\end{array}$ & $\begin{array}{l}\text { Compatibility mission } \\
\text { and objectives are } \\
\text { deliberated. Typically } \\
\text { interface with a } \\
\text { specific project. }\end{array}$ & $\begin{array}{l}\text { A new mission and } \\
\text { goals are shared. For } \\
\text { longer-term results, } \\
\text { one or more projects } \\
\text { and Structure started. }\end{array}$ \\
\hline Responsibilities & $\begin{array}{l}\text { Relationships are } \\
\text { informal; they depend } \\
\text { on the individual } \\
\text { purposes of each } \\
\text { organization. As } \\
\text { requested, the } \\
\text { information shall be } \\
\text { exchanged. }\end{array}$ & $\begin{array}{l}\text { Organizations } \\
\text { perform the required } \\
\text { functions alone. } \\
\text { Contact channels are } \\
\text { established. }\end{array}$ & $\begin{array}{l}\text { A new structure and } \\
\text { formal division shall } \\
\text { be established. } \\
\text { Several channel stages } \\
\text { are established }\end{array}$ \\
\hline
\end{tabular}




\begin{tabular}{|c|c|c|c|}
\hline $\begin{array}{l}\text { Accountability } \\
\text { and authority }\end{array}$ & $\begin{array}{l}\text { Self-government is } \\
\text { solely responsible. } \\
\text { Every organization has } \\
\text { all authority and } \\
\text { responsibility. }\end{array}$ & $\begin{array}{l}\text { Every organization } \\
\text { has authority, but } \\
\text { coordination is in } \\
\text { place. There is some } \\
\text { common risk, but } \\
\text { most of it is still } \\
\text { separate. }\end{array}$ & $\begin{array}{l}\text { Stakeholders defend } \\
\text { agency to equilibrium } \\
\text { ownership. There is } \\
\text { an equal risk. }\end{array}$ \\
\hline Resources & $\begin{array}{l}\text { There are separate } \\
\text { resources. }\end{array}$ & $\begin{array}{l}\text { For a particular } \\
\text { project, resources are } \\
\text { available. }\end{array}$ & $\begin{array}{l}\text { For a long time, } \\
\text { resources have been } \\
\text { pooled. }\end{array}$ \\
\hline
\end{tabular}

The update is often used in the interface of the storyboard panel (Alaloul, M. S. Liew, \& N. A. B. Zawawi, 2016). A particular perspective on relations is given by its conceptual emphasis on coordinated issues rather than co-operation issues: the collaboration perspective focuses on the extent of the partnership agreement, resources contributions, and, consequently, sharing benefits (Alaloul, M. S. Liew, \& N. A. W. A. Zawawi, 2016). The coordinating perspective shows how participants develop their conclusion and management relationships precisely. It is important to notice, as the participants' interests are aligned, that coordination problems cannot be resolved automatically. Coordinating matters, however, require intelligent, vigorous, ongoing, and well-organized efforts. 3C comparison "vision and relationship, structure and responsibility, authority, responsibility, and management of resources" supported. The success of $3 \mathrm{C}$ in construction projects is directly affected by human behaviour. The analysis of behaviour has become an important field of research to improve project performance. 


\section{CONCLUSION}

- Construction projects are characterized by mutually contradictory relationships, fragmented operations, and complexity.

- In the construction industry, 3C's corporate culture, attitude, and strategy aim to improve project efficiency.

- Concentrate on the design and construction phases at the project or organizational level. The potential benefits of this arrangement have yet to be realized in practice, despite an increase in alliance activities.

- This is due to stakeholders' focus on short-term profit sharing and accounting practices, which hurts long-term value creation issues.

- The goal of this document is to fill existing gaps in the project management literature where 3C must be implemented.

\section{REFERENCES}

Alaloul, W. S., M. S. Liew, \& N. A. W. A. Zawawi. (2016). Identification of coordination factors affecting building projects performance. Alexandria Engineering Journal, 55, 2689- 2698.

Alaloul, W. S., M. S. Liew, \& N. A. B. Zawawi. (2016). A Framework for Coordination Process into Construction Projects. MATEC Web of Conferences, 00079.

Alaloul, W. S., M. S. Liew, \& N. A. W. A. Zawawi. (2015). The characteristics of coordination process in construction projects. Technology Management and Emerging Technologies (ISMET), 2015 International Symposium, 159-164.

Alaloul, W., M. Liew, \& N. Zawawi. (2016). Coordination process in construction projects managements in engineering challenges for sustainable future. Proceedings for 3rd International Conference on Civil (ICCOEE) Malaysia, 149, 15-17.

Barkhi, R., A. Amiri, \& T.L. James. (2006). A study of communication and coordination in collaborative software development. Journal of Global Information Technology Management, 6, 44-46. 
Cataldo, M., P.A. Wagstrom, J.D. herbsleb, \& K.M Carley. (2006). Identification of coordination requirements: implications for the Design of Collaboration and awareness tools. Proceddings of the 2006 20th aniverseary conference on Computer Supported cooperative work, 353-362.

Chan, A. P., D. Scott, \& E. W. Lam. (2002). Framework of success criteria for design/build Projects. Journal of management in engineering, 18, 120-128.

Ellingsen, T., \& R. Ostling. (2010). When does communication improve coordination. The American Economic Review, 100, 1695-1724.

Fritz, M., S. Narasimhan, \& H.S Rhee. (1998). Communication and coordination in the virtual office. Journal of management information system, 14, 7-28.

Fuks, H., A. Raposo, M.A. Gerosa, M. Pimental , D. Fillippo, \& C. Lucena. (2008). interand intra-relationships between communication coordination and cooperation in the scope of the 3C collaboration Model. International Conference (CSCWD), 148-153.

Lin, G., \& Q. Shen. (2007). Measuring the performance of value management studies in construction: a critical review. Journal of Management in Engineering, 23, 2-9.

Miller, J. H., \& S. Moser. (2004). Communication and coordination. Complexity, 9, 31-40.

Mohr, J., J. Fisher, \& J.R.Nevin. (1996). Collaborative communication in interfirm relationships: moderating effects of integration an control. Journal of Marketing, 103115.

Xue, X., X. Li, Q.Shen, \& Y. Wang. (2005). An agent-based framework for supply chain coordination in construction. Automation in construction, 14, 413-430. 